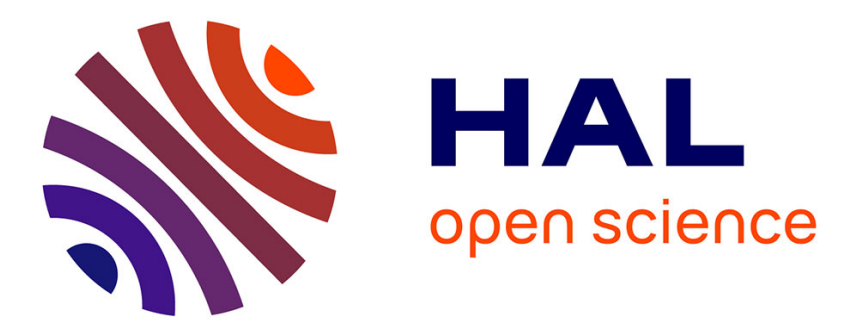

\title{
A New Value Stream Mapping Approach for Engineer-to-Order Production Systems
}

\author{
Maria Kollberg Thomassen, Erlend Alfnes, Erik Gran
}

\section{To cite this version:}

Maria Kollberg Thomassen, Erlend Alfnes, Erik Gran. A New Value Stream Mapping Approach for Engineer-to-Order Production Systems. IFIP International Conference on Advances in Production Management Systems (APMS), Sep 2015, Tokyo, Japan. pp.207-214, 10.1007/978-3-319-22759-7_24 . hal-01431096

\section{HAL Id: hal-01431096 https://hal.inria.fr/hal-01431096}

Submitted on 10 Jan 2017

HAL is a multi-disciplinary open access archive for the deposit and dissemination of scientific research documents, whether they are published or not. The documents may come from teaching and research institutions in France or abroad, or from public or private research centers.
L'archive ouverte pluridisciplinaire HAL, est destinée au dépôt et à la diffusion de documents scientifiques de niveau recherche, publiés ou non, émanant des établissements d'enseignement et de recherche français ou étrangers, des laboratoires publics ou privés.

\section{(c)(1)}

Distributed under a Creative Commons Attribution| 4.0 International License 


\title{
A New Value Stream Mapping Approach for Engineer-To-Order Production Systems
}

\author{
Maria Kollberg Thomassen ${ }^{1, *}$, Erlend Alfnes $^{2}$ and Erik Gran ${ }^{1}$ \\ ${ }^{1}$ SINTEF Technology and Society, Industrial Management, Trondheim, Norway \\ \{maria.thomassen, erik.gran\}@sintef.no \\ ${ }^{2}$ Norwegian University of Science and Technology, Institute of Production and Quality Engi- \\ neering, Trondheim, Norway \\ erlend.alfnes@ntnu.no
}

\begin{abstract}
Companies seeking to implement lean practices in engineer-to-order environments experience major difficulties due to a high degree of non-standard products and non-repetitive processes. Current lean methods need to be further developed to be more efficiently applied in manufacturing environments with high variety and complexity. This paper presents a new approach for value stream mapping adapted to engineer-to-order production systems. The approach combines the classic value stream mapping approach with recent works dealing with lean methods in high mix and complex production systems. Also, it proposes a stronger focus on the choice of location of the customer order decoupling point compared to previous research.
\end{abstract}

Keywords: lean manufacturing · high-mix/low-volume manufacturing · customer order decoupling point

\section{Introduction}

Engineer-to-order (ETO) manufacturing environments are typically characterized by high levels of product and process variation, high product complexity and deep product structures, and low production volumes. Each new order involves product design and development based upon customer specifications. Moreover, design, delivery speed and flexibility are typical order winners and the customer order decoupling point is typically positioned at the very start of production [1].

It is well known that companies that seek to implement lean practices in production environments that involve a high degree of non-standard products and non-repetitive processes, experience major difficulties. Current lean methods therefore need to be further developed before they can be efficiently applied in manufacturing environments with high variety and complexity [2,3]. Despite the growing trend towards increased customization and personalization that imply enhanced variety and complexity in manufacturing, research on the implementation of lean approaches in ETO settings is scarce [e.g. 3, 4]. In this paper focus is on value stream mapping (VSM), a simple and well-known approach to achieve lean flow. The method is developed for 
analysis and improvement in discontinuous flow line manufacturing environments [5], and is most suited for linear product routings and standard products. VSM has three main drawbacks for ETO manufacturing:

- The method does not address the challenges of identifying and mapping value streams in manufacturing environments where the product structure are complex and routings are intertwined.

- Only basic guidelines and techniques for developing lean flow for standard products are included. Techniques that are more sophisticated $[4,6]$ are needed before the method is applicable for customized manufacturing.

- The Customer Order Decoupling Point (CODP) is merely considered as a frame condition for future state design, and how to position the decoupling point is not sufficiently addressed. Positioning the decoupling point is crucial for the performance of engineer-to-order manufacturing and should include an assessment of both engineering and manufacturing lead times.

The purpose of this paper is to create a new value stream mapping approach for the design of flow oriented ETO production systems. The new method integrates the classic VSM method with recent techniques and methods for creating lean flow in high variety and complex manufacturing environments.

\section{Methodological approach}

A review of relevant literature in the lean manufacturing field was carried out with focus on the design of lean production control systems in ETO environments. Several relevant studies were identified and used as a starting point in the development of the approach with a particular emphasis on Duggan's mixed model approach [4] and the improved VSM for complex manufacturing [7]. The identified procedures and processes were reviewed and relevant aspects were selected. Several drafts of the approach have been iteratively discussed and tested during a two-year period in a case company. Since the main focus of this paper is to present the proposed approach, its application in the case company is dealt with only to a limited extent; a simplified version of the current state map that was developed in the case company is included in the paper.

The case company is an ETO manufacturing company of heavy and complex ship equipment. It was critical to get access to in depth and detailed insights of their operations as well as to quantitative data. Moreover, the involvement of company representatives in discussions during the development process has been important.

\section{Review of Literature}

The literature review identified a set of relevant previous works that suggest adjusted lean approaches for various types of high mix low volume manufacturing settings, 
Table 1. These methods are briefly described in the text below. Common for several works is that they are based upon the classic VSM approach [5].

Table 1. Summary of the literature review

\begin{tabular}{|c|c|c|c|}
\hline Approach & Manufacturing setting & Type of method & Focus \\
\hline $\begin{array}{l}\text { Mixed model } \\
\text { value streams [4] }\end{array}$ & $\begin{array}{l}\text { High variety or mix of prod- } \\
\text { ucts or product variations }\end{array}$ & $\begin{array}{l}\text { Step-by-step process } \\
\text { and questions }\end{array}$ & $\begin{array}{l}\text { VSM, future state } \\
\text { mapping }\end{array}$ \\
\hline Improved VSM [7] & $\begin{array}{l}\text { Products with non-linear value } \\
\text { streams }\end{array}$ & $\begin{array}{l}7 \text { step procedure, itera- } \\
\text { tive process }\end{array}$ & $\begin{array}{l}\text { VSM, critical path, } \\
\text { temporized BOM }\end{array}$ \\
\hline $\begin{array}{l}\text { Value network } \\
\text { mapping [8] }\end{array}$ & $\begin{array}{l}\text { Products with dissimilar rout- } \\
\text { ings that share common re- } \\
\text { sources }\end{array}$ & 6 stepwise approach & $\begin{array}{l}\text { Current state map- } \\
\text { ping }\end{array}$ \\
\hline VSM [9] & $\begin{array}{l}\text { MTO products, job shop envi- } \\
\text { ronment }\end{array}$ & $\begin{array}{l}\text { Guidelines, options, } \\
\text { data requirements }\end{array}$ & $\begin{array}{l}\text { Current state and } \\
\text { future state map- } \\
\text { ping }\end{array}$ \\
\hline VSM [10] & $\begin{array}{l}\text { High mix, low volume manu- } \\
\text { facturing, job shop }\end{array}$ & $\begin{array}{l}5 \text { step methodology, } \\
10 \text { questions } \\
\end{array}$ & $\begin{array}{l}\text { Future state map- } \\
\text { ping }\end{array}$ \\
\hline VSM [11] & Batch-of-one environments & 9 step procedure & $\begin{array}{l}\text { Value stream moni- } \\
\text { toring }\end{array}$ \\
\hline $\begin{array}{l}\text { Pacemaker, bottle- } \\
\text { neck, CODP [12] }\end{array}$ & MTO and MTS & 3 steps/guidelines & Future state VSM \\
\hline
\end{tabular}

In brief, several relevant works are identified that deal with MTO and high mix/low volume environments although there are few studies dealing explicitly with specific ETO settings. VSM constitutes a core framework in several studies. There are variations regarding their focus on current state and future state mapping. Several studies present adapted guidelines and stepwise methods. However, few address the choice of CODP location, which is natural as lean implies positioning the CODP as far upstream as is possible in the relevant value stream without interfering with resources shared with other value streams.

\section{$4 \quad$ The Suggested Approach}

The proposed approach for value stream mapping in engineering to order manufacturing is based upon the classic VSM approach [5] and is extended by the other existing studies that have adapted methods for ETO and similar manufacturing situations. The approach is divided into two main parts; the first part (step 1-4) aims at mapping the current state of the value stream while the second part (step 5-11) concentrates on designing its future state. It comprises major steps that may be carried out in a sequential order. However, depending on the complexity of ETO production system, it may be necessary to carry out each step in several iterations as well as to go back and forth between steps. 


\subsection{Step 1: Select Product Family}

This is a critical and challenging task in ETO due to the high complexity of products and irregular process routings. In high-variety/low-volume manufacturing, multiple products with different demand rates and different operations are produced in the same value streams [13]. The product family is essential for defining an appropriate overall scope of the value stream. A product quantity analysis visualizes the product mix in a chart sorting products in order of decreasing production quantity or selling revenue; high volume or high revenue value streams are prioritized [7, 10]. Process routings are mapped to group products according to process commonality in the plant, with focus on downstream processes [4]. A product-process matrix is drawn to make groups of products with the same processing steps; at least 80 percent process commonality is required [4, 7]. A work content matrix is drawn to analyze total operator time variation; less than 30 percent process time variation is required [4]. Products are combined, sorted and revised in several iterations until a suitable family for the value stream is selected.

\subsection{Step 2: Identify Critical Value Stream}

The main critical value stream is a key component branch of a product, typically the processing sequence responsible for the total frame of production time of that product [7]. The bill-of-material (BOM) is mapped for typical products and the lead time is analyzed for each branch. Components on the critical path are identified [11]. A temporized BOM is drawn to graphically visualize the maximum length of lead time needed in the global value stream of supply and production [7]. Shared resources on the critical path are also identified with a distinction between internal and external sharing i.e. when machines are used for different components of the same product, and machines are used by different product families [7].

\subsection{Step 3: Identify Customer Order Decoupling Point}

The inventory locations are analyzed to identify the CODP position of the critical value stream. In an ETO situation, the CODP is typically located upstream in the production process [1]. The CODP is also related to shared resources and bottlenecks [12]. In ETO, the order-based engineering lead time and the order-based production lead time are parts of the delivery time and need to be addressed in the CODP analysis. The CODP is positioned upstream when a key branch of the product includes new elements that are engineered to order.

\subsection{Step 4: Map Critical Value Stream}

The current-state-map is drawn based upon the VSM modelling framework with standard icons and metrics [5]. A high level value stream map is needed since demand rates, process routings, and work content may vary for different products in the value stream [4]. Shared machines, bottlenecks and insertion points where secondary 
branches merge with the critical value stream are defined [7]. Bottleneck resources that cannot be eliminated are managed to ensure balanced flow [5]. An example of a current state map that represents a simplified map of a critical value stream of the case company is shown in Fig. 1.

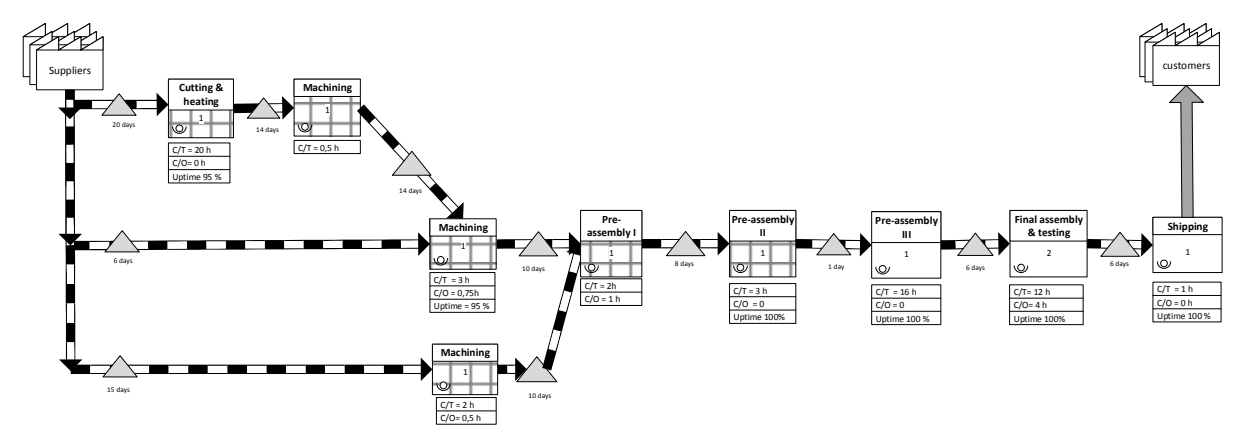

Fig. 1. Example of a current state map of a critical value stream

\subsection{Step 5: Calculate Average Takt Time}

Takt time is defined as the customer demand rate or rhythm [4]. Since a pure takt time control principle is not considered to be appropriate in high-variety, low-volume manufacturing [6], an average takt time is more appropriate for ETO production [13]. The average takt time for the critical value stream that allows for variations is calculated. In order to deal with demand changes, various takt modes are defined based on demand and resources [4].

\subsection{Step 6: Create Continuous Flow Wherever Possible}

To create continuous flow, all the resources needed to perform consecutive activities on the family are dedicated in a set of adjacent cells or lines. The level of process completeness per cell depends on distances between machines, imbalance in cycle times, use of shared resources, and differences in operator skills [4, 14]. Where onepiece flow is not possible, activities are connected into FIFO lanes [4]. FIFO lanes are created between all cells downstream of the CODP. FIFO lanes can be used to create flow between cells/resources that are dedicated to the family, but a single FIFO lane will create flow disruptions if used alone to connect resources that are shared between different product families [4].

\subsection{Step 7: Define the Customer Order Decoupling Point}

A feasible CODP is selected that is the most efficient in terms of combined requirements for customization and short delivery lead-times for the value stream. Since the delivery lead time includes the order-based engineering and production lead time, the CODP is positioned upstream when a key branch of the product includes elements 
that are designed and/or engineered to order. ETO products typically consist of standard components, modules, and sub-assemblies that do not require engineering lead time, elements where the design can be easily modified and some elements that need an extensive engineering lead time. A range of possible inventory points in the sequence of activities at each key component branch are possible CODPs that can separate the order driven flow from the speculation or pull driven flow, but only a few of them can be regarded as feasible CODPs. Feasible CODPs typically have a natural breaking point that correspond to inventory points with the same production lead time in all key branches of the value stream, and allows engineering modifications to be finished before any production activities start [15]. Other factors to take into consideration are demand volatility and volume [1]. A CODP is chosen that minimizes delivery lead time for a given level of customization.

\subsection{Step 8: Create Pull Where Continuous Flow Cannot Be Extended}

Critical points in the value stream, where continuous flow ends and pull must begin, are identified. Pull through supermarkets are often required to buffer between cells with resources that are shared between product families, cells that are located far away from each other and cells with resources that are too unreliable to couple direct in a continuous flow [5]. Many parts, modules and subassemblies in a customized product are standard and can be handled through pure supermarket pull system [16]. Various parts are classified into runners, repeaters, and strangers; runners and some repeaters are typical candidates for a pure pull system [17]. Pure pull is not applicable for custom parts or for strangers, while pull mechanism such as sequential FIFO, generic Kanban, Conwip, and Polca may be used for such parts [18].

\subsection{Step 9: Define the Pacemaker}

The production process that will receive a schedule and set the pace for the entire value stream is defined. The pacemaker process must have equipment dedicated to the product family and is usually in the form of a cell where continuous one-piece flow exist [4]. The pacemaker sets the pace upstream by withdrawing parts through pull systems and downstream by regulating the release of work to maintain FIFO processing flow to the customer. A resource that is shared with other product families cannot easily be a pacemaker because the flow often is too disruptive to follow a takt. In ETO, the position of the pacemaker depends on the position of the CODP because the schedule or work instruction for customized products needs to be sent to the first cell after the CODP $[12,16]$. High-variety/low-volume value streams tend to have an imbalance in capacity between different cells. An obvious bottleneck resource will determine maximum throughput and can be a pacemaker candidate [19].

\subsection{Step 10: Level the Production Mix}

The production of different products is distributed evenly over time. The time intervals that every regular product in the family will be able to run through are specified 
(Every Product Every Interval). A small interval as possible is defined in order to produce the right mix of each part number to satisfy customer demand, and not create excess inventory that is wasteful [5]. Obtaining short intervals mean levelling the mix of products that will run through the pacemaker. For high mixes of product variants, all products are not ordered in every time period. In high mix value streams a level pattern based on product sub-families (Every Family Every Interval) is created [20]. Sub-families are further segmented into runners and strangers. Each runner subfamily represent a fixed time period in the interval. Stranger families are grouped to form one or more periods in the pattern.

\subsection{Step 11: Level the Production Volume}

The production load on the pacemaker process is divided into small consistent amount of production [5]. In high-mix/low-volume manufacturing, the product work content will vary and risks slowing down the pacemaker. If the bottleneck process is different from the pacemaker, capacity constraints at the bottleneck must be taken into consideration in the pacemaker schedule [12]. Orders are thus broken down into equal time increments of work (pitch) based on the bottleneck capacity [16]. In high mix environments the pitch increment is defined to include variations within the family [4]. In order to level the work volume, products are built in a fixed sequence starting from low to high cycle time, products are built ahead in a FIFO lane, products are stored in supermarkets, or labor is added for products that exceed takt time $[4,16]$.

\section{Conclusion}

The literature on ETO adjusted lean methods is scarce and companies meet major challenges when implementing lean in non-repetitive production. We have used the VSM method as the overall structure, and have developed a more comprehensive method that can be used in ETO environments. We have reviewed recent literature on how to create a lean future state in high mix low volume manufacturing. For each step of the original VSM method, we address the specific challenges related to high mix low volume environment, and propose extensions and adaptions to the original method in order to overcome these challenges. The CODP is important, and we have extended the original method with two extra steps to identify the current CODP and determine the future CODP. The method combines various lean methods available in literature that are adapted to non-repetitive manufacturing settings. In contrast to these methods, it highlights the position of the CODP in the current state and future state maps. Further research is needed to refine and validate the method in real life settings. Therefore, further work is planned to utilize the general method to create continuous flow in the case company.

\section{Acknowledgements}

We are grateful for the support of the Research Council of Norway to this research. 


\section{References}

1. Olhager, J., Strategic positioning of the order penetration point. International Journal of Production Economics, 2003. 85(3): p. 319-329.

2. Melchert, E.R., M.A. de Mesquita, and P.G. Francischini. Lean manufacturing on make-toorder suppliers: a case study. in 12th International Conference on Industrial Engineering and Operations Management (ICIEOM). 2006.

3. Matt, D.T. and E. Rauch, Implementing Lean in Engineer-to-Order Manufacturing: Experiences from. Handbook of Research on Design and Management of Lean Production Systems, 2014: p. 148.

4. Duggan, K.J., Creating mixed model value streams: practical lean techniques for building to demand. 2013, Boca Raton, Fla.: Taylor \& Francis. XX, 238 s. : ill. + 1 CD-ROM.

5. Rother, M. and J. Shook, Learning to see: value stream mapping to add value and eliminate muda. 2003: Lean Enterprise Institute.

6. Krishnamurthy, A. and R. Suri, Planning and implementing POLCA: a card-based control system for high variety or custom engineered products. Production planning and control, 2009. 20(7): p. 596-610.

7. Braglia, M., G. Carmignani, and F. Zammori, A new value stream mapping approach for complex production systems. International journal of production research, 2006. 44(18-19): p. 3929-3952.

8. Khaswala, Z. and S.A. Irani. Value network mapping (VNM): visualization and analysis of multiple flows in value stream maps. in Proceedings of the Lean Management Solutions Conference. 2001.

9. da CL Alves, T., I.D. Tommelein, and G. Ballard. Value stream mapping for make-to-order products in a job shop environment. 2005. Construction Research Congress.

10. Araya, J.M., Value stream mapping adapted to high-mix, low-volume manufacturing environments. 2012.

11. Stamm, M. and T. Neitzert, Value stream mapping (VSM) in a manufacture-to-order small and medium enterprise. 2008.

12. Serrano, I., R. de Castro, and A. Goienetxea, Pacemaker, Bottleneck and Order Decoupling Point in Lean Production Systems. International Journal of Industrial Engineering: Theory, Applications and Practice, 2009. 16(4).

13. Slomp, J., J.A. Bokhorst, and R. Germs, A lean production control system for highvariety/low-volume environments: a case study implementation. Production Planning and Control, 2009. 20(7): p. 586-595.

14. Alfnes, E., Enterprise reengineering-a strategic framework and methodology. 2005, Norwegian University of Science and Technology.

15. Wikner, J. and M. Rudberg, Integrating production and engineering perspectives on the customer order decoupling point. International Journal of Operations \& Production Management, 2005. 25(7): p. 623-641.

16. Rother, M. Value stream mapping in a make-to-order environment. 2005.

17. Lane, G., Made-to-order lean: excelling in a high-mix, low-volume environment. 2007, New York: Productivity Press. XIII, 209 s. : ill.

18. Bicheno, J., The lean toolbox for service systems. 2008: PICSIE books.

19. Yang, T. and J.-C. Lu, The use of a multiple attribute decision-making method and value stream mapping in solving the pacemaker location problem. International journal of production research, 2011. 49(10): p. 2793-2817.

20. Bohnen, F., T. Maschek, and J. Deuse, Leveling of low volume and high mix production based on a group technology approach. CIRP Journal of Manufacturing Science and Technology, 2011. 4(3): p. 247-251. 